Copyright by the Ecological Society of America. K. S. Simon, M. A. Simon, and E. F. Benfield 2009 . Variation in ecosystem function in Appalachian streams along an acidity gradient. Ecological Applications 19:1147-1160. http:// $\mathrm{dx}$.doi.org/10.1890/08-0571.1

Ecological Applications, 19(5), 2009, pp. 1147-1160

(C) 2009 by the Ecological Society of America

\title{
Variation in ecosystem function in Appalachian streams along an acidity gradient
}

\author{
K. S. Simon, ${ }^{1,4}$ M. A. Simon, ${ }^{2}$ And E. F. Benfield ${ }^{3}$ \\ ${ }^{1}$ School of Biology and Ecology, University of Maine, Orono, Maine 04469-5722 USA \\ ${ }^{2}$ Department of Biology, James Madison University, Harrisonburg, Virginia 22807 USA \\ ${ }^{3}$ Department of Biology, Virginia Polytechnic Institute and State University, Blacksburg, Virginia 24061 USA
}

\begin{abstract}
Acidification is a widespread phenomenon that damages aquatic systems, and it has been the focus of intensive management efforts. While most management has focused on community structure as an endpoint, ecosystem function is also sensitive to acidification and important in stream health. We examined how a key ecosystem function in streams, leaf breakdown, varied along a gradient of $\mathrm{pH}$ resulting from acid deposition, natural conditions, and liming. We also measured how invertebrate and microbial assemblage structure and microbial function were related to altered leaf breakdown rates. Leaf breakdown rates declined more than threefold along a gradient of stream acidity from $\mathrm{pH} 6.8$ to 4.9 . The diversity of leaf-shredding invertebrates, bacteria, and fungi showed little response to variation in $\mathrm{pH}$. The abundance of one acid-sensitive caddisfly, Lepidostoma, declined with acidification, and Lepidostoma abundance explained 37\% of the variation in leaf breakdown rates among sites. Microbial respiration was suppressed along the acidity gradient, although the pattern was weaker than that for breakdown rate. In short-term laboratory incubations, microbes at acidic and circumneutral sites demonstrated adaptation to ambient $\mathrm{pH}$. The activity of microbial extracellular enzymes was strongly influenced by $\mathrm{pH}$. In particular, the pattern of activity of phosphatase indicated increasing $\mathrm{P}$ limitation of microbes with increasing acidification. Our results show that leaf breakdown is a sensitive tool for examining the response of stream function to acidification and also for defining the mechanisms that drive functional response. Future management efforts should focus on key taxa that are particularly sensitive and effective at shredding leaves and also the role of shifting acidity in mediating the availability of phosphorus to microbial films that are important for stream function.
\end{abstract}

Key words: acid precipitation; bacteria; decomposition; ecosystem function; fungi; George Washington National Forest, USA; leaf breakdown; liming; microbial diversity; stream restoration; Virginia, USA.

\section{INTRODUCTION}

Acid deposition has degraded terrestrial and freshwater systems, and despite reductions in sulfate emissions, acidification remains a widespread problem (Schindler 1988, Driscoll et al. 2001). Damage to freshwater systems includes reduced diversity and altered assemblages of algae, amphibians, invertebrates, and fish (Townsend et al. 1983, Mulholland et al. 1992, Driscoll et al. 2001), and such structural components of ecosystems have been the primary targets of assessment and restoration. However, ecosystem processes, such as decomposition (Hildrew et al. 1984, Dangles et al. 2004), primary production (Mulholland et al. 1986, Niyogi et al. 2002a), and bacterial production (Mulholland et al. 1992), also are sensitive to acidification, yet they are not commonly considered in assessment and restoration efforts. The use of leaf breakdown in particular has been suggested as a simple, effective tool for evaluating the

Manuscript received 2 April 2008; revised 26 September 2008; accepted 12 November 2008. Corresponding Editor: K. N. Eshleman.

${ }^{4}$ E-mail: ksimon@maine.edu effects of acidification and other pollutants in streams (Niyogi et al. 2001, 2003b, Gessner and Chauvet 2002, Dangles et al. 2004). Because the breakdown of leaves is a critical pathway of energy flux in food webs of forested streams (Wallace et al. 1997), alterations to this process may have large effects on whole stream communities. A further advantage of using leaf breakdown in assessment is that it integrates a variety of abiotic and biotic factors over time, particularly microbial and invertebrate assemblages, which are involved in regulating the rate of this key ecosystem process in streams. The diversity of influencing factors can present a problem when factors are confounded or if there are compensatory effects among factors (Gesssner and Chauvet 2002), but it also presents an opportunity to define specific mechanisms that drive functional response to stress when appropriate ancillary data are collected (e.g., Niyogi et al. 2001). This type of mechanistic information is important for designing management strategies that will successfully restore stream function.

Future changes in acid deposition and implementation of restoration activities such as liming will likely result in continuing changes in stream acidity of varying 
magnitude. While many studies have shown that the breakdown rate of leaves in streams can be slowed by acidification (e.g., Mulholland et al. 1987, Dangles et al. 2004), few have measured whether this function can be restored (McKie et al. 2006, Merrix et al. 2006), and it is unclear what abiotic and biotic factors will be important in determining successful restoration. Restoration efforts have relied largely on the application of neutralizing compounds, especially lime, to whole catchments, lakes, and streams (Weatherly 1988). These compounds are delivered by a variety of mechanisms including aerial application to uplands and direct addition of buffering compounds to streams by mechanical dosers or periodic addition of large amounts of material directly to streams. Such restoration efforts target $\mathrm{pH}$ levels, typically $\mathrm{pH}>6.2$, that are expected to support acidsensitive animals, especially fish (e.g., Eggleton et al. 1996). It is unknown if this target is appropriate for recovery of ecosystem function. In general, restoration efforts have met with mixed success. Water chemistry often improves, but the change is typically spatially and temporally variable (McClurg et al. 2007). In some cases, an improvement in water chemistry is accompanied by increased invertebrate and fish abundance and diversity (e.g., Hudy et al. 2000). However, in many cases, liming has improved water chemistry but yielded only limited restoration of the abundance or diversity of invertebrates and fish (e.g., Eggleton et al. 1996, McClurg et al. 2007). The response of ecosystem function to liming has received far less attention, but a few studies have shown that liming may restore leafbreakdown rates to reference levels in some streams (McKie et al. 2006, Merrix et al. 2006). Indirect evidence suggested the recovery of breakdown rates in those studies was largely due to restoration of microbes rather than invertebrates, but the response of microbial diversity and function to changing acidity is poorly understood despite the importance of microbial processes in streams and the sensitivity of microbes to acidification (Niyogi et al. 2003a).

Streams of the Appalachian Mountains have been subjected to substantial changes in acidity as a result of human action including acidic precipitation and restoration efforts, especially liming (Herlihy et al. 1993, McClurg et al. 2007). These activities have resulted in streams that span a gradient in acidity and the influence of changing acidity on invertebrate and fish assemblages is well studied (e.g., Hudy et al. 2000, McClurg et al. 2007). The responses of microbial assemblages and ecosystem function to altered acidity are more poorly known. Our goal was to examine how rates of leaf breakdown change along a gradient of acidity in Appalachian streams to determine the sensitivity and utility of this ecosystem function for stream management. In addition, we examined the abundance and diversity of invertebrates and microbes and several measures of microbial function to address how specific mechanisms that drive leaf breakdown changed along the acidity gradient. To do this, we compared leaf breakdown in sites distributed among several streams subjected to acid precipitation and liming that spanned a gradient of $\mathrm{pH}$ values representative of those found in regional streams.

\section{Methods \\ Site description}

We used multiple sites in two drainages (Little Stony Creek (38 $\left.56^{\prime} 16^{\prime \prime} \mathrm{N}, 78^{\circ} 38^{\prime} 47^{\prime \prime} \mathrm{W}\right)$ and Mountain Run $\left(38^{\circ} 29^{\prime} 37^{\prime \prime} \mathrm{N}, 78^{\circ} 42^{\prime} 8^{\prime \prime} \mathrm{W}\right)$ in the George Washington National Forest of western Virginia, USA. These streams are rocky bottomed and surrounded by a dense canopy of mixed hardwood forest. Both drainages receive acid precipitation and have been treated by direct addition of limestone sand to stations in the streams. Little Stony Creek was treated in two locations five times between September 1989 and July 2001. Mill Creek, a tributary to Little Stony Creek, was treated in a single location in September 1989 and July 2001. Mountain Run was treated in one location in 1993. Details of the limestone applications and chemical changes resulting from the liming are summarized by Downey et al. (1994) and Hudy et al. (2000). The streams were acidic $(\mathrm{pH}<5.0)$ prior to the liming, which increased $\mathrm{pH}$ and acid neutralizing capacity and reduced total aluminum in the water downstream of the liming stations. At Little Stony Creek, $\mathrm{pH}$ rose from 5.0 to 6.8 , on average (range 5.8-7.8), in the three years immediately after the first liming. Liming increased $\mathrm{pH}$ in Mill Creek from 4.8 to 6.3, on average (range 5.3-7.3), in the three years following the first liming. At Mountain Run, $\mathrm{pH}$ rose from 4.5 to 5.6, on average (range 5.07.2), during the first four years following liming. Our study began in November 2003 which was two years after the last limestone addition to Little Stony Creek and Mill Creek and 14 years after limestone addition to Mountain Run. We used three sites on Little Stony Creek that were above (LS1), between (LS2), and below (LS3) the two liming stations on the stream (Fig. 1). We sampled one site above (MC1) and one below (MC2) the liming station on Mill Creek. We sampled seven sites in the Mountain Run drainage (Fig. 1). Mountain Run was limed near where the stream appears on the surface of the ground so we could not sample upstream of the liming site. Instead, we sampled four sites (MR1, MR2, MR3, and MR4) below the liming station, and used one site in an un-limed tributary (AT) as an acidic reference site. We also used two sites (BT1 and BT2) in a second tributary to Mountain Run that is underlain by a small limestone area in its catchment as naturally buffered reference sites. We deployed leaf packs at each site on 12 November 2003 and subsequently sampled water and recovered packs after 28, 63, 98, 133, 176, and 219 days.

\section{Water chemistry}

On each sampling date, 1-L acid-washed HDPE bottles were filled completely under water and returned 
to the laboratory for determination of $\mathrm{pH}$ and conductivity. $\mathrm{pH}$ and conductivity were measured using an electronic meter (sensION 2, Hach Company, Loveland, Colorado, USA). We analyzed filtered (Whatman $\mathrm{GF} / \mathrm{F}$ glass fiber filters, $0.7 \mu \mathrm{m}$ ) aliquots of water from each site except BT1 on three dates (day 23, 68, and 176) for soluble reactive phosphorus using the ascorbic acid method (APHA 1999). Nitrate concentration in filtered aliquots was determined on one date (day 23) for all sites using a Lachat Quikchem 8500 flow-injection analyzer (Hach Company). Discharge on each sampling date was calculated by measuring cross-sectional area of the stream and mean water velocity with an electronic flow meter (Flo-Mate; Marsh-McBirney, Frederick, Maryland, USA). Water temperature at each site was recorded at hourly intervals throughout the study using iButton temperature loggers (Maxim Integrated Products, Sunnyvale, California, USA).

\section{Leaf packs}

At each site we deployed 18 packs of chestnut oak (Quercus prinus) leaves, a common tree at all study sites. Leaves were collected after abscission from a single tree, dried to a constant mass at room temperature, and placed into mesh bags $(8 \mathrm{~g} /$ pack, mesh size $=2 \mathrm{~cm})$. The leaf packs were attached to a cable anchored in the stream at each site. Three leaf packs were carried to the sites and returned to the laboratory to determine initial percentage of ash-free dry mass (AFDM) and mass loss resulting from handling. On each sampling date, three leaf packs were removed from the stream at each site, placed individually into plastic bags with a small amount of stream water and transported on ice directly to the laboratory and processed. In the laboratory, pieces of leaf $(\sim 2 \mathrm{~g}$ wet mass) were clipped from individual leaves randomly chosen from each bag and used for measurement of microbial respiration, extracellular enzyme activity, and fungal biomass.

For microbial respiration, approximately half of the clipped leaf pieces were placed into $26-\mathrm{mL}$ serum vials that contained stream water from the collection site (Niyogi et al. 2003b). The vials were sealed and incubated at $10^{\circ} \mathrm{C}$ for $6-10$ hours with gentle stirring during the incubation. Respiration rates on the leaf pieces were determined as differences between dissolved oxygen concentrations in the vials containing leaves and that in control vials containing only stream water. Dissolved oxygen concentration was measured with an electronic meter (YSI Model 85; YSI, Yellow Springs, Ohio, USA), and preliminary trials revealed that oxygen uptake was linear during the course of the incubations. To determine whether microbial communities demonstrated adaptation to $\mathrm{pH}$, we cross-incubated leaves from the most buffered (BT2) and most acidic (AT) sites in water from the opposite site and compared the respiration rates to those measured on leaves incubated in water from their own collection site as described.

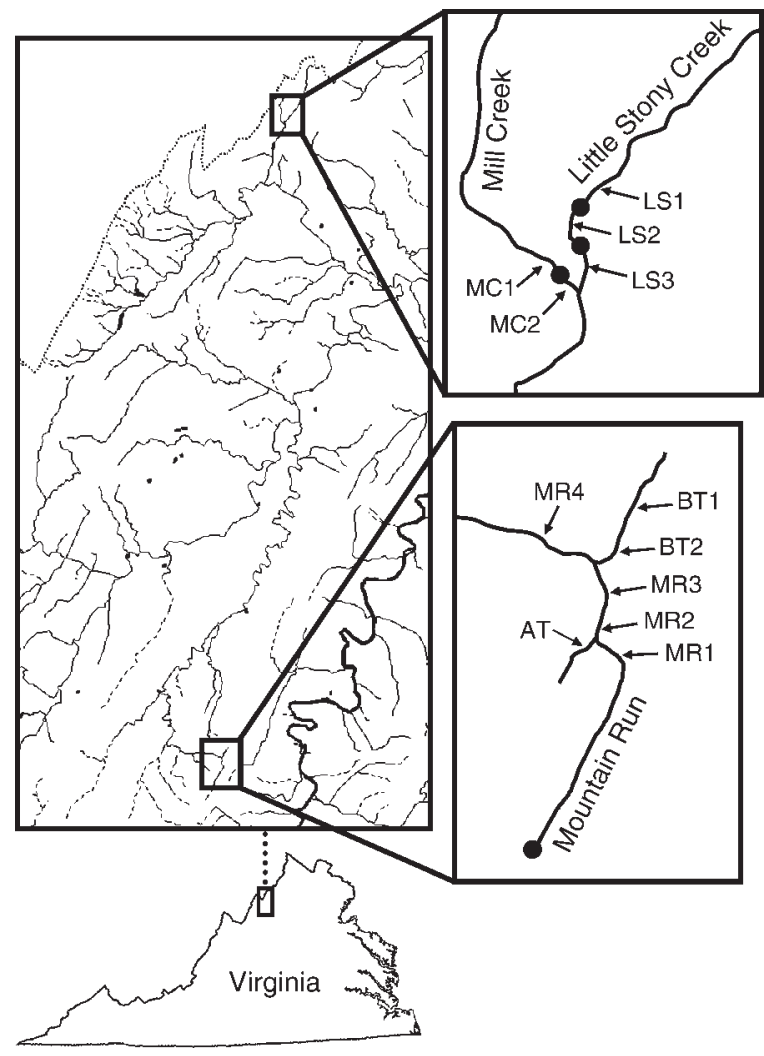

FIG. 1. Location of the study sites in the Little Stony Creek and Mountain Run drainages in the George Washington National Forest, western Virginia, USA. Solid circles indicate locations of liming stations.

Half of the leaf pieces not used for respiration was frozen at $-80^{\circ} \mathrm{C}$ until processing for extracellular enzyme activity. We assayed activity of three extracellular enzymes, $\alpha$-1,4-glucosidase (GLUC), $\beta$-1,4-xylosidase (XYLO), and phosphatase (PHOS), using methylumbelliferone-labeled substrates (4-MUB- $\alpha-\mathrm{D}$ glucopyranoside, 4-MUB- $\beta$-D-xylopyranoside, and 4MUB phosphate, respectively). The leaf pieces were thawed and homogenized in $30 \mathrm{~mL}$ of $50 \mathrm{mmol} / \mathrm{L}$ acetate (for $\mathrm{pH}<5.5$ ) or bis-tris (for $\mathrm{pH}>5.5$ ) buffer that was adjusted to match the $\mathrm{pH}$ of the site at the time of collection. Two hundred microliters of the leaf slurry were added to 96-well microplates. Fifty microliters of a $200 \mu \mathrm{mol} / \mathrm{L}$ substrate solution was added to each well and fluorescence was measured at $25^{\circ} \mathrm{C}$ using a microplate fluorometer (Fluoroskan Ascent FL; Thermo Scientific, Waltham, Massachusetts, USA). Quench, sample, substrate, and reference standard controls were used. Because these assays measure activity as the amount of substrate cleaved during an incubation, any differences in enzyme activity observed among sites could be due to a direct effect of $\mathrm{pH}$ on enzyme speed (i.e., the rate at which enzymes operate) or differences in enzyme production, either amount or enzyme structure, by microbes on the leaves in the streams. To help 
discriminate between these, we determined the direct effect of $\mathrm{pH}$ on enzyme activity on a set of subsamples of leaves collected on day 98 of the study from a single site (BT2) in the naturally buffered stream. The subsamples were incubated at $\mathrm{pH} 4.8,5.4,6.0,6.6$, and 7.2 (ambient $\mathrm{pH}$ in BT2). We compared the trend in enzyme activity from that experiment to the trend observed among sites on that date.

Fungal biomass was estimated as ergosterol content of biofilms on leaves (Newell et al. 1988). The leaf pieces not used for respiration and enzyme assays were refluxed in $5 \mathrm{~mL}$ of methanol for $2 \mathrm{~h}$ at $65^{\circ} \mathrm{C}$. The samples were cooled, saponified by adding $1 \mathrm{~mL}$ of $4 \% \mathrm{KOH}$ in methanol, and then refluxed for $0.5 \mathrm{~h}$ at $65^{\circ} \mathrm{C}$. The samples were cooled, centrifuged, and the supernatants were decanted into clean tubes. The pellets were resuspended in $2 \mathrm{~mL}$ of methanol, centrifuged, and the supernatant was added to that from the first wash. The supernatants were then extracted twice with 2-mL aliquots of pentane. The pentane extracts were evaporated under a stream of $\mathrm{N}_{2}$ and the residue was redissolved in $1 \mathrm{~mL}$ of methanol and filtered through a $0.45-\mu \mathrm{m}$ filter. Ergosterol was quantified using an HPLC system (VP Series; Shimadzu, Kyoto, Japan; the solvent was methanol; the column was Nova-Pak ODS C18 (Waters, Milford, Massachusetts, USA; flow rate $=2$ $\mathrm{mL} / \mathrm{min}$; absorbance $=282 \mathrm{~nm}$ ).

After the leaf packs were sampled for microbial assays, the remaining contents of the mesh bags were rinsed over a $250-\mu \mathrm{m}$ mesh sieve. Invertebrates were sorted from the leaves, preserved in $80 \%$ ethanol, and the leaf-shredding taxa (according to Merritt and Cummins 1996) were later removed and enumerated. The remaining leaves, and the leaves from the microbial assays, were dried at $60^{\circ} \mathrm{C}$, weighed, combusted at $500^{\circ} \mathrm{C}$ for $1 \mathrm{~h}$, rewetted, dried at $60^{\circ} \mathrm{C}$, and weighed to determine AFDM.

\section{Microbial community structure}

Bacterial and fungal assemblage structure was examined using denaturing-gradient gel electrophoresis (DGGE) on leaf samples collected from each site, except BT1 and MR3, on day 98. Day 98 was selected because it was near the midpoint of the study and a period of high microbial activity and leaf mass loss. Leaf fragments $\left(\sim 1 \mathrm{~cm}^{2}\right.$ from each of three packs) were removed from the packs using sterile forceps and scissors. DNA was extracted from $\sim 0.1 \mathrm{~g}$ of the leaf fragments using a PowerSoil DNA Isolation Kit (MO BIO Laboratories, Carlsbad, California, USA). Bacterial 16S rDNA genes were amplified from DNA extracts with the bacteria-specific $16 \mathrm{~S}$ rRNA primers $357 \mathrm{~F}-\mathrm{GC}$ (5'-GCclamp-CCT ACG GGA GGC AGC AG-3') and 907R (5'-CCG TCA ATT CMT TTG ACT TT-3') (Muyzer and Smalla 1998) designed to amplify the V4 and V5 region. Fungal DNA was amplified with the fungal ITS primers, ITS3-GC (5'-CGCCCG CCGCGC CCCGCG CCCGGC CCGCCG CCCCCG CCCC
GCA TCG ATG AAG AAC GCAGC-3') and ITS4 (5'-TCC TCC GCT TAT TGA TAT GC-3') (Nikolcheva et al. 2005, Raviraja et al. 2005). Amplification was carried out in $50-\mu \mathrm{L}$ reactions containing $1 \mu \mathrm{L}$ DNA template, $0.2 \mu \mathrm{M}$ of each primer, $0.2 \mathrm{mmol} / \mathrm{L}$ dNTPs, 2.5 units Taq polymerase with $1 \times$ buffer $(1.5 \mathrm{mM}$ $\mathrm{MgCl}_{2}, 50 \mathrm{mM} \mathrm{KCl}, 10 \mathrm{mM}$ Tris; Fisher Scientific, Pittsburgh, Pennsylvania, USA). Amplicons were analyzed by DGGE with a D-Code System (Bio-Rad, Hercules, California) on $8 \%(\mathrm{w} / \mathrm{v})$ polyacrylamide gels using a 30-55\% gradient (where $100 \%$ denaturant contains $7 \mathrm{~mol} / \mathrm{L}$ urea and $40 \%$ formamide) for the bacterial $16 \mathrm{~S}$ primers and a $30-60 \%$ gradient for the fungal primers. Electrophoresis was carried out in $1 \times$ TAE (40 mM Tris, $20 \mathrm{mM}$ acetic acid, $1 \mathrm{mM}$ EDTA) buffer at $70 \mathrm{~V}$ for 15 hours at $60^{\circ} \mathrm{C}$ for bacterial primers and $50 \mathrm{~V}$ for 15 hours at $56^{\circ} \mathrm{C}$ for ITS primers. Gels were stained with SYBRGold (1:10000 dilution; Molecular Probes, Eugene, Oregon, USA) for $30 \mathrm{~min}$ and visualized on a UV transilluminator (GelDoc; BioRad, Hercules, California, USA).

\section{Data analyses}

Leaf breakdown rates $(k)$ were calculated by regressing the natural $\log (\ln )$ of mean percentage AFDM remaining against time (Webster and Benfield 1986). Breakdown rates were compared among sites within each stream using analysis of covariance (ANCOVA) with a dummy variable technique (Kleinbaum et al. 1988). Mean values of water chemistry were compared among sites in each stream using ANCOVA with time as a covariate. We examined microbial decomposition efficiency by calculating turnover activities for each enzyme. Turnover activity is calculated much like $k$, except that in percentage AFDM remaining is regressed against cumulative enzyme activity (units of activityday). The inverse of the slope of this relationship (moles per gram) represents an estimate of the amount of enzymatic "work" required to break down a cohort of litter or, in the case of phosphatase, acquire $\mathrm{P}$ during breakdown (Sinsabaugh et al. 1991, 2002). The relationships between $\mathrm{pH}$ and leaf breakdown rate, microbial respiration, ergosterol, mean enzyme activity and turnover activity, and shredder abundance across all sites were examined using linear regression. Regressions involving enzyme data used $\log _{10}$-transformation to linearize the relationships. Multiple regression was used to examine the combined effects of individual invertebrate taxa and microbial parameter rates of leaf breakdown. Differences in respiration during the crossincubation experiment were tested for using a threefactor analysis of variance (ANOVA) with leaf source, water source, and time as factors. Data were lntransformed as needed to meet assumptions of normality and homogeneity of variance, and all statistics were run using SAS v. 9.1 (SAS Institute, Cary, North Carolina, USA). Results were considered statistically significant at $\alpha=0.05$. 
TABLE 1. Mean chemical parameters over the 215-day study period and leaf breakdown rate $(k)$ in the study area in the George Washington National Forest, western Virginia, USA.

\begin{tabular}{|c|c|c|c|c|c|c|c|c|c|c|}
\hline \multirow[b]{2}{*}{ Stream and site } & \multicolumn{2}{|c|}{$\mathrm{pH}$} & \multicolumn{2}{|c|}{ Conductivity $(\mu \mathrm{S} / \mathrm{cm})$} & \multicolumn{2}{|c|}{ Temperature $\left({ }^{\circ} \mathrm{C}\right)$} & \multicolumn{2}{|c|}{ Discharge $(\mathrm{L} / \mathrm{s})$} & \multirow{2}{*}{$\begin{array}{c}\mathrm{NO}_{3}^{-} \\
(\mu \mathrm{g} \mathrm{N} / \mathrm{L})^{\dagger}\end{array}$} & \multirow[b]{2}{*}{$k\left(\mathrm{~d}^{-1}\right)$} \\
\hline & Mean & Range & Mean & Range & Mean & Range & Mean & Range & & \\
\hline \multicolumn{11}{|l|}{ Mt. Run } \\
\hline AT & $4.9^{\mathrm{d}}$ & $4.8-5.0$ & $22.2^{b, c}$ & $21.5-24.1$ & 7.4 & $1.8-14.0$ & $17^{\mathrm{c}}$ & $4-33$ & 12 & $0.0020^{\mathrm{c}} \pm 0.0002$ \\
\hline MR1 & $5.6^{\mathrm{c}}$ & $5.3-5.9$ & $18.9^{\mathrm{d}}$ & $16.9-20.8$ & 6.8 & $1.0-14.5$ & $33^{\mathrm{b}, \mathrm{c}}$ & $5-49$ & 10 & $0.0019^{c} \pm 0.0002$ \\
\hline MR2 & $5.4^{\mathrm{c}}$ & $5.2-5.5$ & $19.3^{\mathrm{c}}$ & $17.0-21.2$ & 6.8 & $0.5-14.5$ & $51^{\mathrm{a}, \mathrm{b}}$ & $27-85$ & 15 & $0.0014^{\mathrm{c}} \pm 0.0003$ \\
\hline MR3 & $5.6^{\mathrm{c}}$ & $5.3-5.8$ & $19.0^{\mathrm{d}}$ & $16.9-20.6$ & 6.4 & $0.5-15.0$ & $50^{\mathrm{a}}$ & $30-82$ & 29 & $0.0020^{\mathrm{c}} \pm 0.0003$ \\
\hline MR4 & $6.3^{\mathrm{b}}$ & $5.8-6.9$ & $19.2^{\mathrm{c}, \mathrm{d}}$ & $18.5-20.2$ & 7.5 & $0.5-16.5$ & $70^{\mathrm{a}}$ & $32-104$ & 28 & $0.0034^{\mathrm{b}, \mathrm{c}} \pm 0.0006$ \\
\hline BT1 & $6.7^{\mathrm{a}, \mathrm{b}}$ & $6.5-6.9$ & $24.7^{\mathrm{a}, \mathrm{b}}$ & $22.5-27.7$ & 7.6 & $0.5-16.5$ & $18^{\mathrm{c}}$ & $7-22$ & 59 & $0.0041^{\mathrm{a}, \mathrm{b}} \pm 0.0009$ \\
\hline BT2 & $6.8^{\mathrm{a}}$ & $6.5-6.9$ & $25.6^{\mathrm{a}}$ & $22.5-30.3$ & 7.2 & $0.5-16.5$ & $20^{\mathrm{b}, \mathrm{c}}$ & $8-31$ & 39 & $0.0051^{\mathrm{a}} \pm 0.0010$ \\
\hline \multicolumn{11}{|l|}{ Little Stony Creek } \\
\hline LS1 & $5.9^{\mathrm{a}}$ & $5.6-6.3$ & 18.3 & 16.8 & 6.5 & $0.5-15.5$ & 207 & $90-385$ & 92 & $0.0026 \pm 0.0004$ \\
\hline LS2‡ & $6.0^{\mathrm{a}, \mathrm{b}}$ & $5.6-6.3$ & 18.5 & $17.3-19.0$ & 6.3 & $0.5-15.5$ & 250 & $107-377$ & 77 & $0.0028 \pm 0.0003$ \\
\hline LS3\% & $6.1^{\mathrm{a}}$ & $5.7-6.5$ & 19.0 & $18.1-19.8$ & 6.2 & $0.5-16.0$ & 232 & $131-389$ & 90 & $0.0024 \pm 0.0004$ \\
\hline \multicolumn{11}{|l|}{ Mill Creek } \\
\hline $\mathrm{MCl}$ & $5.4^{\mathrm{b}}$ & $5.3-5.4$ & $22.3^{\mathrm{a}}$ & 23.9 & 6. & 7.5 & 87 & & 63 & $0.0026 \pm 0.0004$ \\
\hline MC $2 \ddagger$ & $5.8^{\mathrm{a}}$ & $5.4-6.2$ & $21.1^{\mathrm{b}}$ & $19.6-22.2$ & 6.9 & $0.5-16.5$ & 63 & $12-103$ & 168 & $0.0032 \pm 0.0004$ \\
\hline
\end{tabular}

Notes: Within each stream, sites that share a common letter are not significantly different (ANCOVA, $P<0.05, n=6$ ). Values for $k$ are means \pm SE.

$\dagger$ Values for $\mathrm{NO}_{3}^{-}$are for a single sample collected on day 28.

$\ddagger$ Site is below a liming station.

DGGE bands were detected and quantified using Quantity One version 4.5.2 software (Bio-Rad, Hercules, California, USA). We did not identify the taxa associated with each band; therefore, we refer to individual bands as operational taxonomic units (OTUs; Reche et al. 2005). The total number of bands for each site was used as an index of bacterial and fungal taxonomic richness $(S)$. Richness and the relative intensity of each band within each sample were used to calculate Shannon diversity $\left(H^{\prime}\right.$; Reche et al. 2005). DGGE profiles were compared among sites with regard to presence and absence of bands using cluster analysis according to the unweighted pair group method (UPGMA) method using Quantity One software.

\section{RESUlts}

\section{Abioitic characteristics of sites}

Mean $\mathrm{pH}$ across all sites fell between 4.9 in the acidic tributary (AT) and 6.8 in the naturally buffered tributary (BT1 and BT2) to Mountain Run (Table 1). Over the course of the study, $\mathrm{pH}$ varied by $0.1-0.8$ units within each site (Table 1), but there was no trend of increasing or declining $\mathrm{pH}$ over time. Sites downstream of the liming station in Mountain Run were $0.5-1.4 \mathrm{pH}$ units higher than in AT and highest below the confluence with the naturally buffered tributary. In Little Stony Creek, mean $\mathrm{pH}$ was moderately acidic $(\sim \mathrm{pH} 6.0)$ and similar in sites above and below the liming stations. In Mill Creek, mean $\mathrm{pH}$ was on the acidic end $(\mathrm{pH}<5.9)$ of the gradient across sites and modestly higher ( $0.4 \mathrm{pH}$ units) below the liming station. Conductivity was generally low in all sites and differed by $<6 \mu \mathrm{S} / \mathrm{cm}$ among sites (Table 1 ). Soluble reactive phosphorus was below our method detection limit $(1 \mu \mathrm{g}$
$\mathrm{P} / \mathrm{L}$ ) at all sites on all dates in which we attempted to measure it. Nitrate concentration ranged from 10 to 168 $\mu \mathrm{g} \mathrm{N} / \mathrm{L}$ across sites on the first sampling date (Table 1). Water temperature ranged from just above freezing to $17.5^{\circ} \mathrm{C}$ during the experiment and differed by $<1.8^{\circ} \mathrm{C}$, on average, across all sites (Table 1). Discharge was highest in Little Stony Creek followed by Mill Creek, and there were no differences among sites within those streams (Table 1). At Mountain Run, discharge was $\sim 75 \%$ lower in the tributaries (AT, BT1, BT2) than in the most downstream sampling station (MR4) on Mountain Run.

\section{Leaf breakdown rates}

Across all sampling sites there were strong positive relationships between $k$ and $\mathrm{pH}$ (Fig. 2A; $P<0.001, R^{2}$ $=0.72)$ and conductivity $\left(P=0.010, R^{2}=0.50\right)$. The variation in the rate of leaf breakdown across sites was not explained by temperature $\left(P=0.137, R^{2}=0.21\right)$, discharge $\left(P=0.621, R^{2}=0.03\right)$, or $\mathrm{NO}_{3}{ }^{-}$concentration $\left(P=0.448, R^{2}=0.06\right)$. In the Mountain Run drainage, leaves broke down 2-3.6 times faster in the naturally buffered tributary (BT1 and BT2) than in the upstream sites (MR1-MR3) in Mountain Run and the acidic tributary (AT; Table 1). The breakdown rate at the site on Mountain Run (M4) below the confluence with the buffered tributary was intermediate between the more acidic upstream sites and the buffered tributary. There were no differences $(P>0.05)$ in $k$ between the sites located above and below liming stations on Little Stony Creek or Mill Creek (Table 1).

\section{Invertebrate colonization of leaf packs}

Twelve different leaf-shredding taxa were present across all sites, but the stoneflies Amphinemura and 

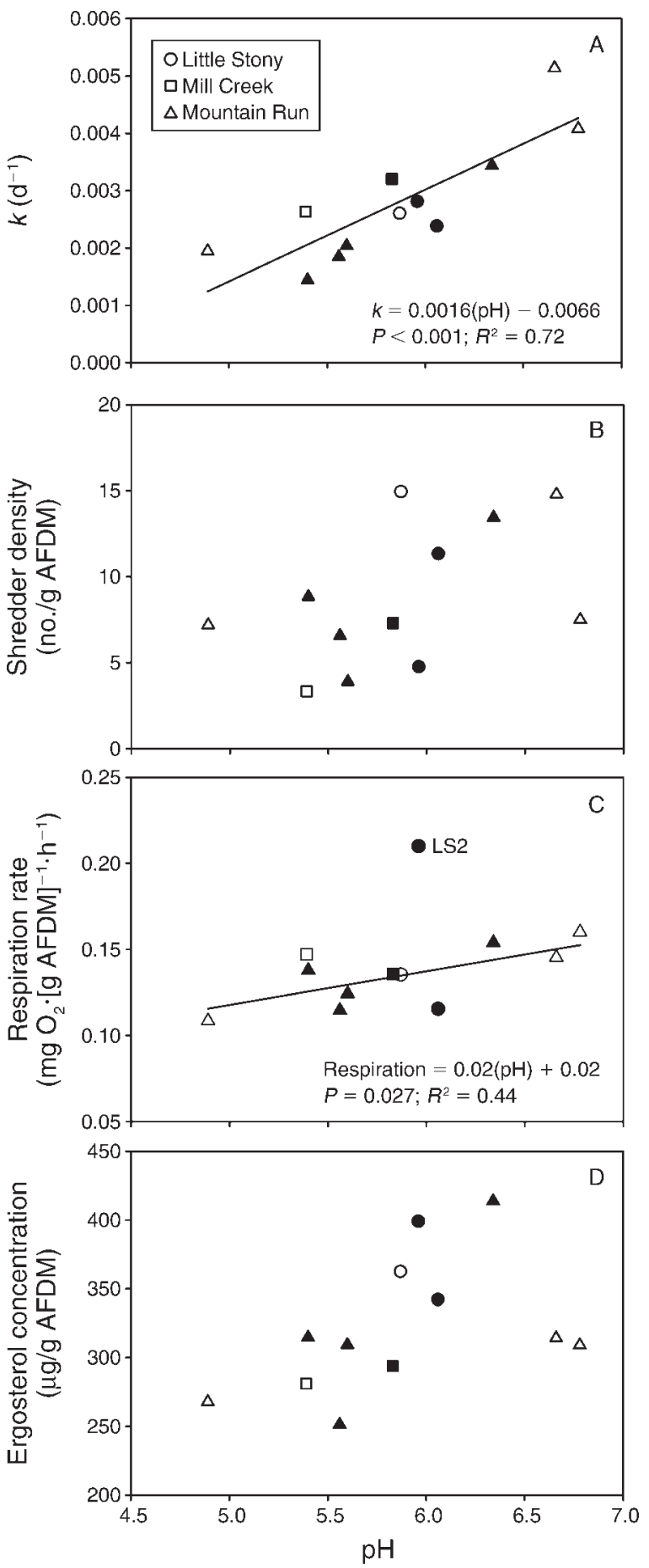

FIG. 2. Relationships between $\mathrm{pH}$ and (A) leaf breakdown rate $(k),(\mathrm{B})$ density of leaf-shredding invertebrates, $(\mathrm{C})$ rate of microbial respiration, and (D) ergosterol concentration in leaf packs in three study streams. Values for $\mathrm{pH}$, shredding invertebrates, respiration, and ergosterol are means $(n=6)$ over the 219-day study. Lines indicate results of statistically significant $(P<0.05)$ linear regressions for $(A)$ all sites and $(C)$ all sites except LS2. Solid symbols are sites below liming stations.
Leuctra and the caddisflies Lepidostoma and Ostrocerca accounted for the majority $(>86 \%)$ of individuals at all sites. Neither mean shredder richness nor Shannon diversity differed among sites $(P>0.510$; Table 2$)$ or were related to $\mathrm{pH}(P>0.248)$. Across all sites, total abundance of shredders was weakly related to mean $\mathrm{pH}$ (Fig. 2B; $\left.P=0.099, R^{2}=0.25\right)$ and unrelated to $k(P=$ 0.208). Of the individual invertebrate taxa, only the abundance of Lepidostoma was related to variation in $k$ across sites $\left(P=0.036, R^{2}=0.37\right.$; Fig. $\left.3 \mathrm{~A}\right)$, and its abundance also was positively related to $\mathrm{pH}(P=0.017$, $\left.R^{2}=0.669\right)$.

\section{Microbial activity and diversity}

The relationship between $\mathrm{pH}$ and fungal biomass, as ergosterol, and microbial respiration differed between drainages. In the Mountain Run drainage, mean rates of microbial respiration were $\sim 40 \%$ higher in the naturally buffered tributary and in the most downstream station in Mountain Run (MR4) than in the acidic tributary, and there was a strong, positive relationship between respiration and $\mathrm{pH}$ across sites $\left(P=0.009, R^{2}=0.77\right.$; Fig. 2C). Furthermore, the microbial communities in the naturally buffered and acidic tributaries demonstrated adaptation to ambient $\mathrm{pH}$. There were significant effects of leaf $\left(F_{1,68}=5.4, P=0.025\right)$ and water $\left(F_{1,68}=12.0, P\right.$ $=0.001)$ source, and time $\left(F_{5,68}=12.2, P<0.001\right)$ on respiration rates in the cross-incubation experiment. Importantly, there was a strong interaction between leaf and water source $\left(F_{1,68}=77.2, P<0.001\right)$ indicating the microbial films on leaves from the two sites differed in their response to water of differing $\mathrm{pH}$. When leaves from the most buffered site (BT2) were incubated in

TABLE 2. Taxon richness $(S)$ and Shannon diversity $\left(H^{\prime}\right)$ of leaf-shredding invertebrates (shredders), bacteria, and fungi on leaves.

\begin{tabular}{|c|c|c|c|c|c|c|}
\hline \multirow{2}{*}{$\begin{array}{l}\text { Stream } \\
\text { and site }\end{array}$} & \multicolumn{2}{|c|}{ Shredders } & \multicolumn{2}{|c|}{ Bacteria } & \multicolumn{2}{|c|}{ Fungi } \\
\hline & $S$ & $H^{\prime}$ & $S$ & $H^{\prime}$ & $S$ & $H^{\prime}$ \\
\hline \multicolumn{7}{|l|}{ Mt. Run } \\
\hline AT & $4.3(0.4)$ & $0.9(0.1)$ & 19 & 2.8 & 16 & 2.6 \\
\hline MR1† & $4.0(0.6)$ & $0.9(0.1)$ & 19 & 2.9 & 15 & 2.6 \\
\hline MR2 $\dagger$ & $3.8(0.7)$ & $0.7(0.1)$ & 21 & 2.9 & 16 & 2.6 \\
\hline MR3† & $3.8(0.5)$ & $0.9(0.1)$ & nd & nd & nd & nd \\
\hline MR4 $\dagger$ & $4.8(0.4)$ & $0.9(0.1)$ & 19 & 2.8 & 18 & 2.8 \\
\hline BT1 & $4.5(0.9)$ & $1.1(0.2)$ & nd & nd & nd & nd \\
\hline BT2 & $5.2(0.2)$ & $1.2(0.2)$ & 22 & 2.9 & 18 & 2.7 \\
\hline \multicolumn{7}{|c|}{ Little Stony } \\
\hline LS1 & $5.5(0.6)$ & $1.2(0.1)$ & 21 & 2.8 & 12 & 2.3 \\
\hline $\mathrm{LS} 2 \dagger$ & $5.5(0.6)$ & $1.3(0.1)$ & 20 & 2.6 & 12 & 2.4 \\
\hline LS3† & $4.7(0.4)$ & $1.2(0.1)$ & 21 & 2.9 & 16 & 2.6 \\
\hline \multicolumn{7}{|l|}{ Mill Creek } \\
\hline $\mathrm{MCl}$ & $5.2(0.3)$ & $1.2(0.1)$ & 20 & 2.6 & 15 & 2.6 \\
\hline $\mathrm{MC} 2 \dagger$ & $6.0(0.6)$ & $1.4(0.1)$ & 23 & 3.0 & 11 & 2.3 \\
\hline
\end{tabular}

Notes: Values for shredders are means across all sampling dates (days 1-215) with SE in parentheses $(n=6)$. Values for bacteria and fungi are from day 98. Entries of "nd" indicate "no data."

$\dagger$ Site is below a liming station. 

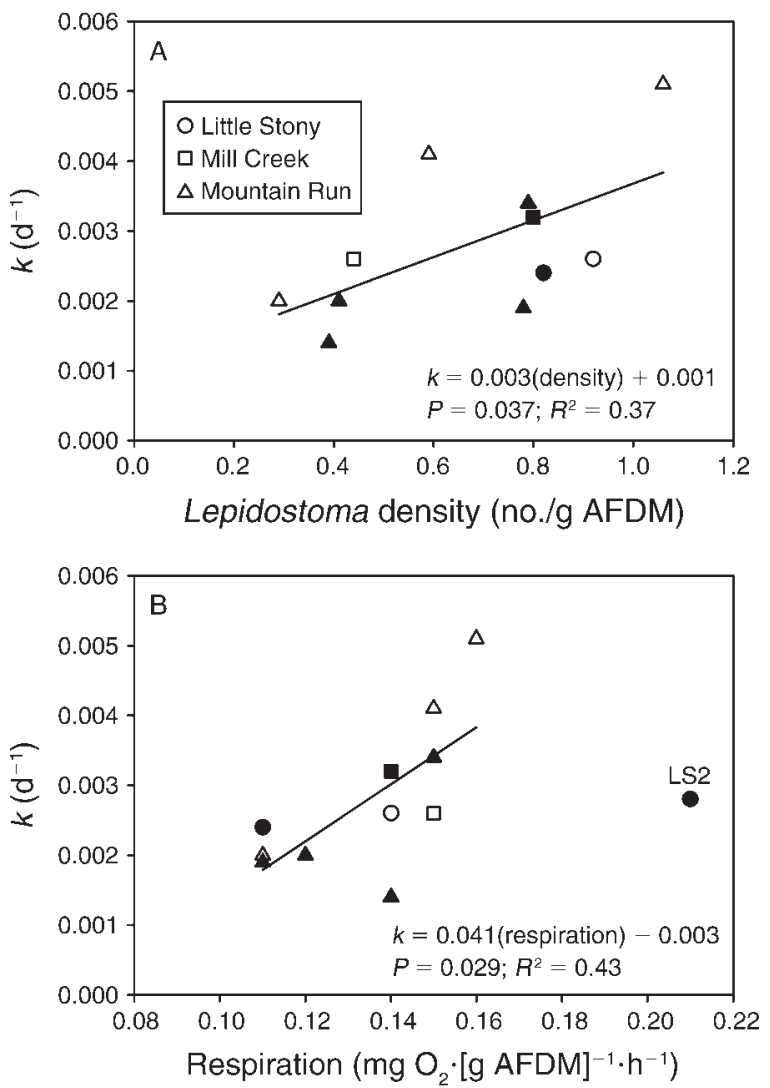

FIG. 3. Relationships between leaf breakdown rate $(k)$ and (A) Lepidostoma abundance and (B) mean rate of microbial respiration in leaf packs. Lines are linear regressions for (A) all sites and (B) all sites except LS2. Solid symbols are sites below liming stations.

water from the acidic site (AT), respiration rates were $\sim 60 \%$ lower than when the leaves were incubated in BT2 water (Fig. 4). In contrast, microbial respiration rates on leaves from the acidic site (AT) were $42-60 \%$ higher in the acidic water than when incubated in the more buffered water from BT2 (Fig. 4). Across sites in all three streams, neither fungal biomass nor microbial respiration were strongly related to $\mathrm{pH}(P>0.121$; Fig. $2 \mathrm{C}, \mathrm{D})$, and neither variable was related to $k(P>$ 0.135). However, when we excluded a single site (LS2) that had particularly high respiration compared to all other sites, microbial respiration was positively related to both $\mathrm{pH}\left(P=0.027, R^{2}=0.44\right.$; Fig. $\left.2 \mathrm{C}\right)$ and $k(P=$ $0.017, R^{2}=0.49$; Fig. $3 \mathrm{~B}$ ). The combination of microbial respiration and abundance of Lepidostoma explained $49 \%$ of the variation in $k$ among all sites, and when site LS2 was excluded, the model explained $60 \%$ of the variation in $k$ (Table 3 ).

The overall mean activity of the three enzymes we assayed rose nonlinearly with increasing acidity among sites; however, the most acidic site (AT) was an outlier with much lower enzyme activity than expected, considering the relationship between $\mathrm{pH}$ and the other sites (Fig. 5). Despite the outlier, there was a strong negative relationship between $\mathrm{pH}$ and the activity of glucosidase (GLUC; $P<0.001, R^{2}=0.69$ ), $\beta-1,4$ xylosidase (XYLO; $P<0.001, R^{2}=0.81$ ), and phosphatase (PHOS; $P=0.001, R^{2}=0.65$ ) across sites. Enzyme activity also was negatively related to leaf breakdown rate. The mean activity of GLUC $(P=0.007$, $\left.R^{2}=0.53\right)$, XYLO $\left(P<0.001, R^{2}=0.80\right)$, and PHOS $(P$ $\left.=0.004, R^{2}=0.57\right)$ explained much of the variation in $k$ across sites. Turnover activities also rose dramatically in a nonlinear fashion with declining $\mathrm{pH}$ (Fig. 6), with $\mathrm{pH}$ explaining most $\left(P<0.001, R^{2}>0.83\right)$ of the variation in turnover activity among sites for all enzymes.

While activity of all three enzymes demonstrated similar patterns across sites, the underlying causes of those patterns differed among enzymes. For XYLO, the direct effect of reducing $\mathrm{pH}$ on enzyme activity measured on BT2 leaf subsamples was similar to the pattern among sites, indicating that a direct effect of $\mathrm{pH}$ on enzyme activity, rather than differences in enzyme production, drove differences in XYLO activity among sites (Fig. 7A). For GLUC, activity on BT2 leaves increased when we experimentally lowered $\mathrm{pH}$, but the activity on leaves from sites at $\mathrm{pH}<5.5$ activity was lower than that on BT2 enzymes at similar $\mathrm{pH}$, indicating GLUC production was suppressed in sites with $\mathrm{pH}<5.5$ (Fig. 7B). PHOS activity on BT2 leaves was unresponsive to experimental manipulation of $\mathrm{pH}$,

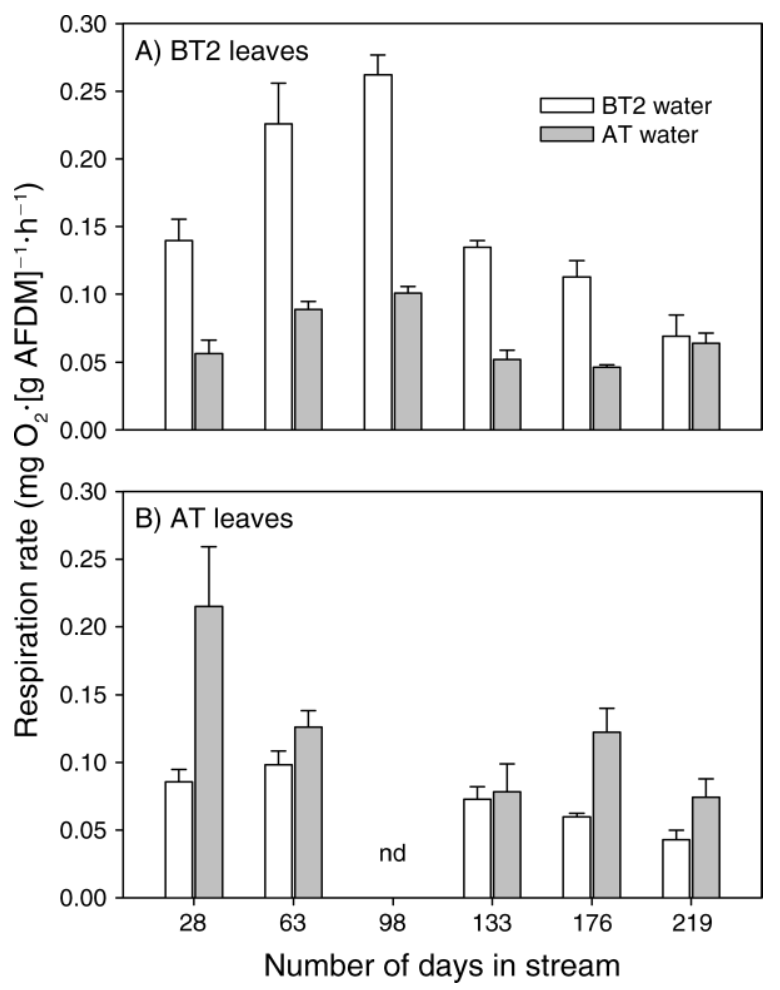

FIG. 4. Rates of microbial respiration (mean $+\mathrm{SE}$ ) on leaves from sites (A) BT2 and (B) AT incubated in water from each site on each collection date; "nd" indicates "no data." 
TABLE 3. Multiple regression analysis of rate of leaf breakdown (log-transformed) in relation to microbial respiration and Lepidostoma abundance (both log-transformed) across all sites and with site LS2 excluded.

\begin{tabular}{|c|c|c|c|c|c|c|c|}
\hline Sites & $\mathrm{df}$ & Overall $R^{2}$ & Overall $F$ & Overall $P$ & $\begin{array}{l}\text { Independent } \\
\text { variable }\end{array}$ & $\begin{array}{c}\text { Standardized } \\
\text { regression coefficient }\end{array}$ & $P$ \\
\hline All sites & 2,11 & 0.49 & 4.30 & 0.049 & respiration & 0.36 & 0.182 \\
\hline LS2 excluded & 2,10 & 0.60 & 5.93 & 0.026 & $\begin{array}{l}\text { Lepidostoma } \\
\text { respiration } \\
\text { Lepidostoma }\end{array}$ & $\begin{array}{l}0.51 \\
0.50 \\
0.46\end{array}$ & $\begin{array}{l}0.070 \\
0.065 \\
0.089\end{array}$ \\
\hline
\end{tabular}

but PHOS activity rose dramatically across sites, indicating that increasing PHOS production with declining $\mathrm{pH}$ drove the pattern in PHOS activity observed among sites (Fig. 7C).

Using denaturing gradient gel electrophoresis (DGGE) we detected 34 and 35 different operational taxonomic units (OTUs) for bacteria and fungi, respectively, among all sites (Fig. 8). For bacteria, individual sites contained $56-68 \%$ of the total OTUs detected across all sites, and community similarity ranged from $44-83 \%$ between individual sites. Within each drainage, sites with highest $\mathrm{pH}$ often had higher bacterial and fungal taxon richness ( $S$; Table 2$)$, but the differences were not large and $S$ was unrelated to $\mathrm{pH}(P$ $=0.271)$ and $k(P=0.317)$ across all streams. For fungi, individual sites contained $31-51 \%$ of the total OTUs detected across sites, and community similarity ranged from $33-71 \%$ between individual sites. Within Mountain Run and Little Stony Creek, sites with higher $\mathrm{pH}$ had higher $S$, but this pattern was reversed in Mill Creek. As for bacteria, fungal $S$ was not related to $\mathrm{pH}(P=0.539)$ or $k(P=0.593)$ across all sites. Bacterial and fungal $H^{\prime}$ followed patterns similar to that of $S$ and also were unrelated to $\mathrm{pH}(P>0.610)$. For the two sites at the extreme range of $\mathrm{pH}$ (BT2 and AT), fungal assemblage composition was quite different in that they shared only about half of the total OTUs they contained and the two sites fell quite distantly in the cluster analysis (Fig. 8). The bacterial assemblages at these two sites were more similar than for fungi, with the two sites clustering closer and sharing $85 \%$ of their OTUs. Overall, bacterial and fungal assemblages did not cluster cleanly by either stream or by $\mathrm{pH}$ (Fig. 8).

\section{DisCUSSION}

Leaf breakdown is a strong candidate for successfully monitoring the response of ecosystem function to stress because it is sensitive to a variety of abiotic and biotic factors that are susceptible to human activity (Gessner and Chauvet 2002). The primary abiotic factors that drive the pace of leaf breakdown include temperature, discharge, leaf chemistry, and water chemistry (including nutrients, pollutants, and $\mathrm{pH}$ ), and these factors exert a strong influence on the abundance and activity of microbes and invertebrates that break down leaves (Webster and Benfield 1986). In our study, neither temperature nor discharge explained the variation in $k$

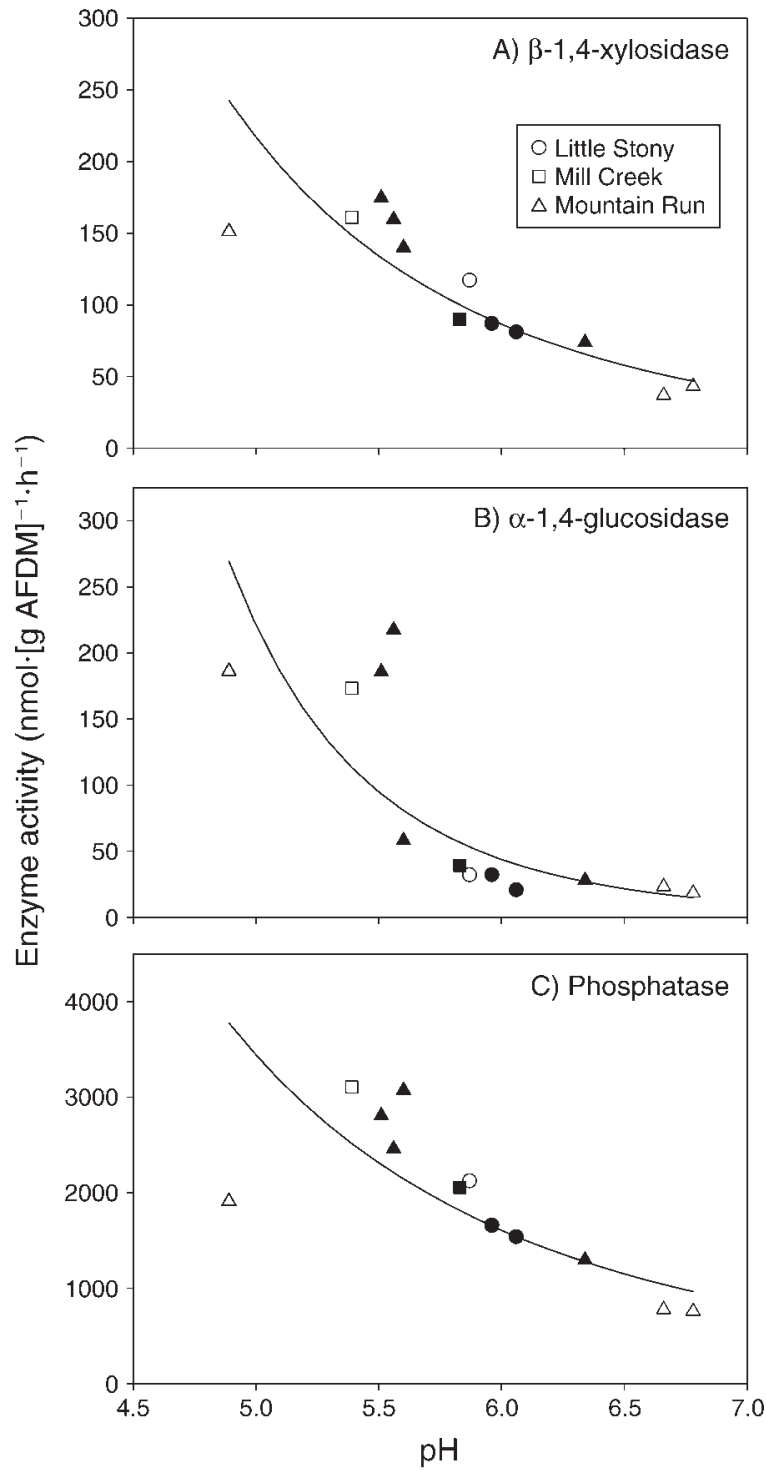

FIG. 5. Relationships between $\mathrm{pH}$ and mean activity of (A) $\beta$-1,4-xylosidase (XYLO), (B) $\alpha$-1,4-glucosidase (GLUC), and (C) phosphatase (PHOS) among sites over the 219-day study. Lines are linear fits to $\log _{10}$-transformed data: XYLO $=$ $-5.0(\mathrm{pH})+5.9\left(P<0.001, R^{2}=0.81\right), \mathrm{GLUC}=-8.9(\mathrm{pH})+$ $8.6\left(P<0.001, R^{2}=0.72\right)$, and PHOS $=-4.2(\mathrm{pH})+6.5(P=$ $\left.0.001, R^{2}=0.65\right)$. Solid symbols are sites below liming stations. 

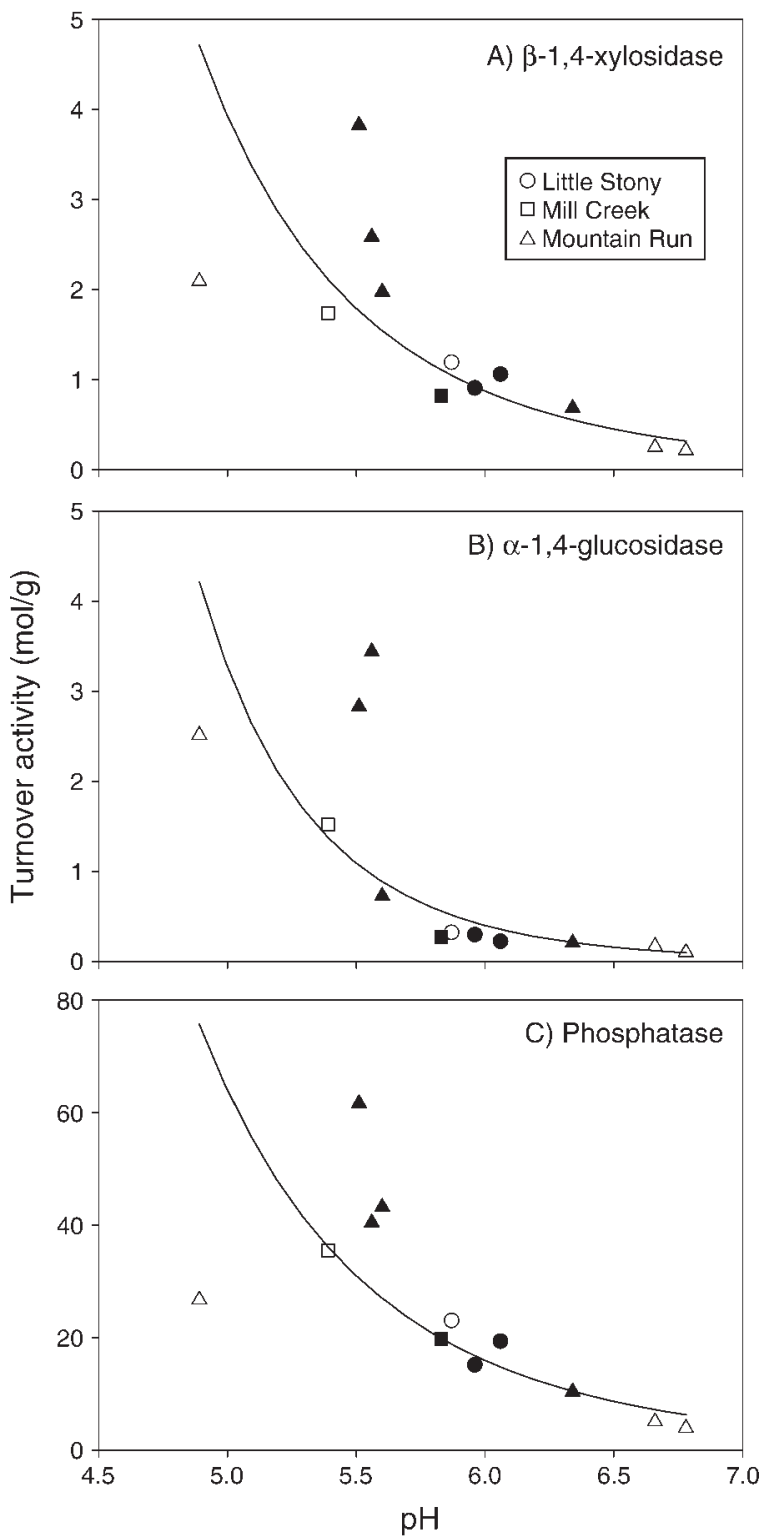

FIG. 6. Relationships between $\mathrm{pH}$ and turnover activity of (A) $\beta$-1,4-xylosidase, (B) $\alpha$-1,4-glucosidase, and (C) phosphatase among sites over the 219-day study. Lines are linear fits to $\log _{10}$-transformed data: XYLO $=-8.2(\mathrm{pH})+6.3(P<0.001$, $\left.R^{2}=0.87\right)$, GLUC $=-11.5(\mathrm{pH})+8.6\left(P<0.001, R^{2}=0.87\right)$, and PHOS $=-7.6(\mathrm{pH})+7.1\left(P<0.001, R^{2}=0.83\right)$. Solid symbols are sites below liming stations.

we observed across sites, and the use of a single leaf type precluded any leaf chemistry effects.

Leaf breakdown rate was strongly related to variation in $\mathrm{pH}$ across sites, and the pattern and magnitude of reduced $k$ with reduced $\mathrm{pH}$ (a factor of 2-3.6) was within the range (a factor of 2-10) of reduced $k$ reported for similar $\mathrm{pH}$ ranges in other studies (Mulholland et al. 1992, Dangles et al. 2003, 2004). The reduction in $k$ with increased acidity is typically associated with suppression of invertebrates and microbes, either alone or together (e.g., Mulholland et al. 1987, Dangles and Guerold 1998, Niyogi et al. 2001). In our study, much (49-60\%) of the variation in leaf breakdown across the $\mathrm{pH}$ gradient in our streams was explained by the combined influence of one leaf-shredding insect, Lepidostoma, and microbial respiration.

Reduced abundances of shredders or loss of particular taxa with high shredding efficiencies are commonly considered to be the primary cause of reduced leaf breakdown under acidification (e.g., Dangles and Guerold 1998, 2001). In our study, the composition of the shredder assemblage was similar across sites, and neither the diversity nor total abundance of shredders explained the differences in $k$ among our sites, appar-
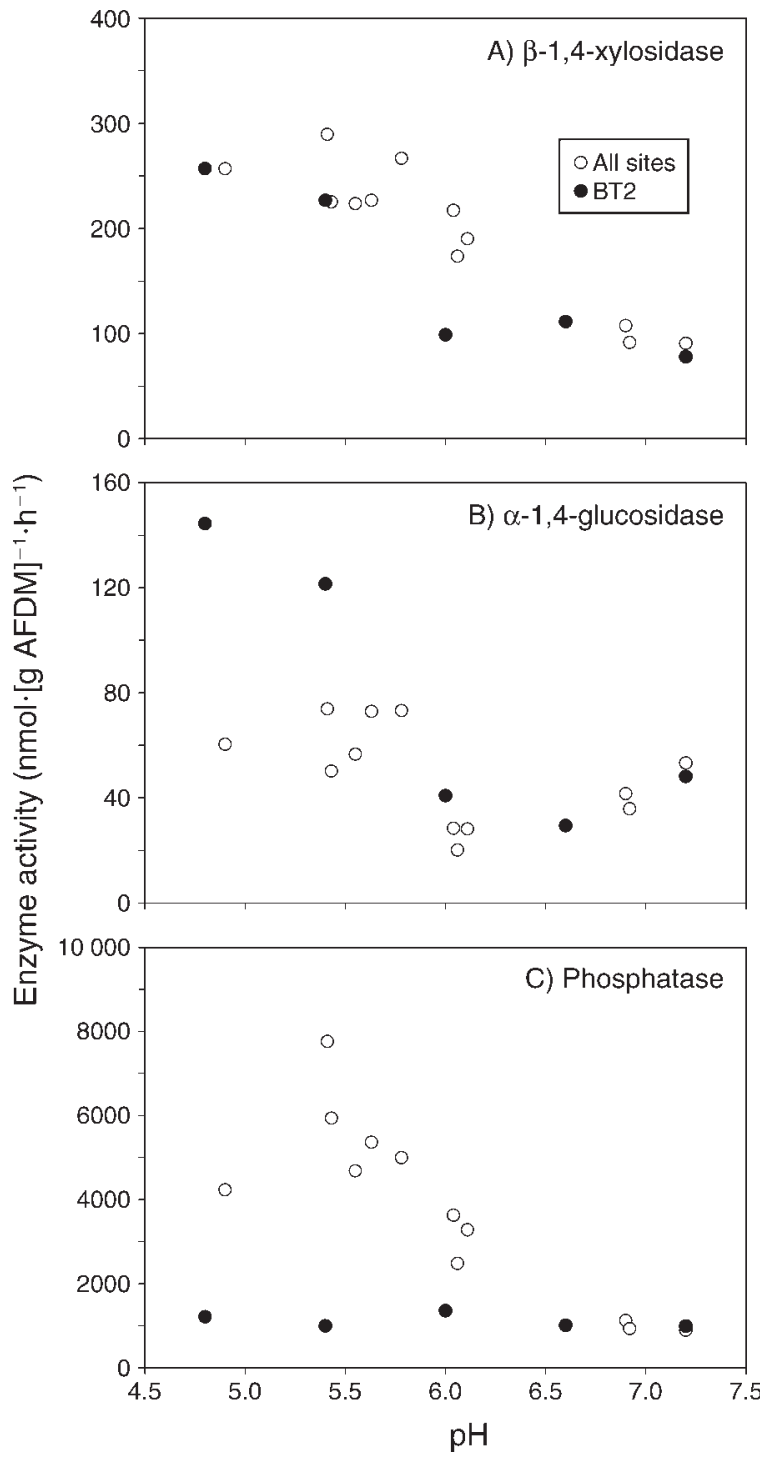

FIG. 7. Relationships between $\mathrm{pH}$ and activity of (A) $\beta-1,4-$ xylosidase, (B) $\alpha$-1,4-glucosidase, and (C) phosphatase among sites on day 98 (open symbols) and on subsamples of leaves from site BT2 measured at five different $\mathrm{pH}$ values (solid symbols). 

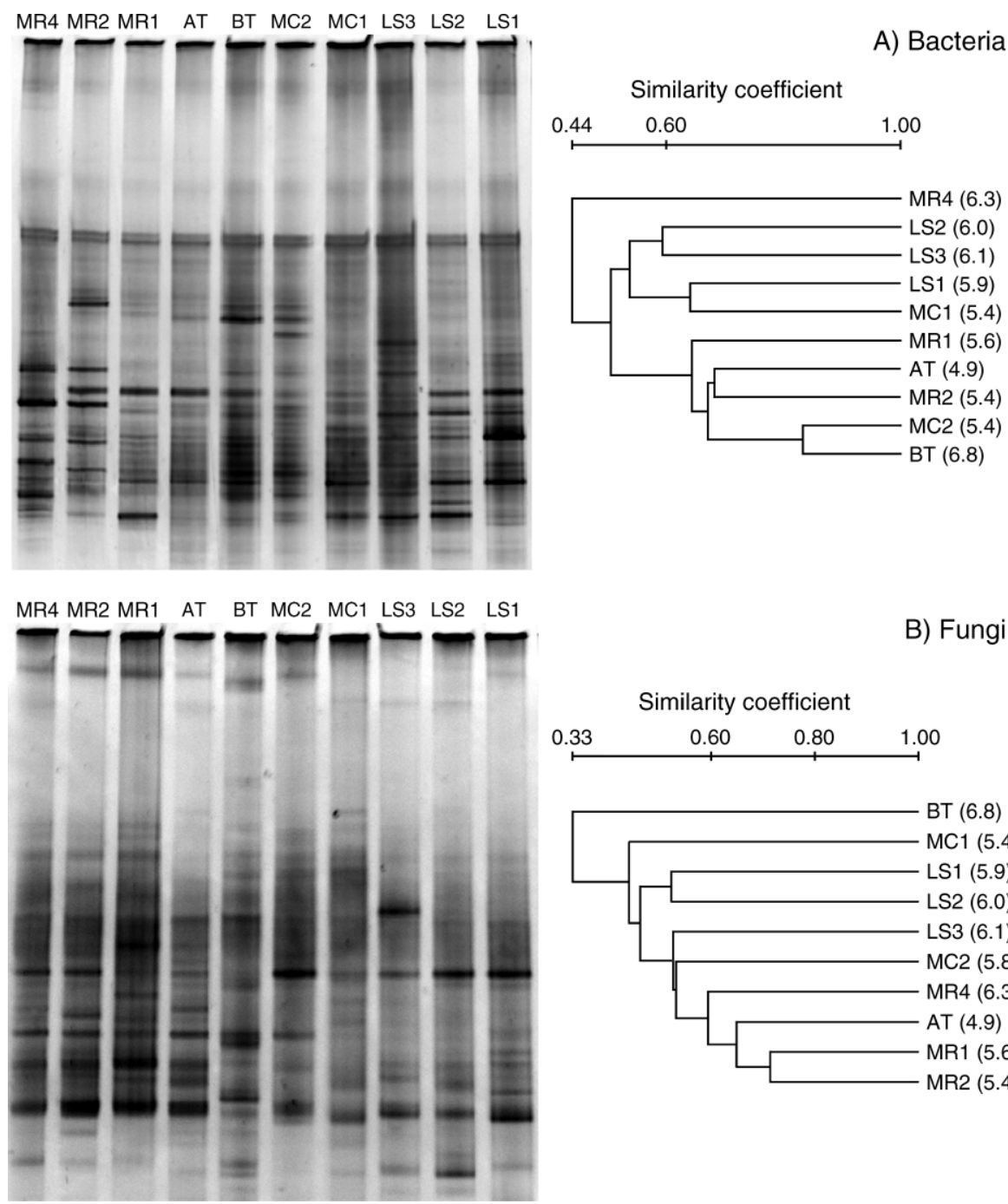

B) Fungi

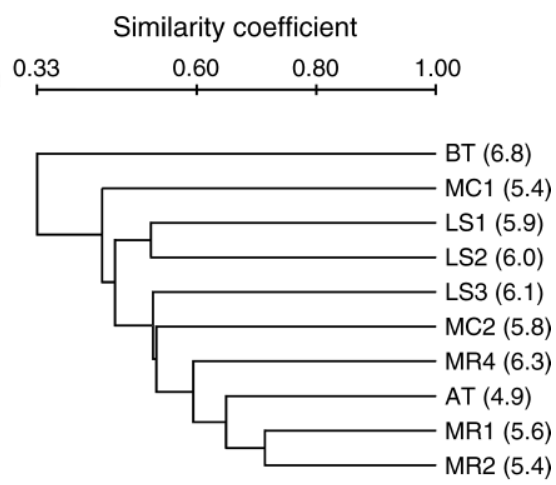

FIG. 8. Denaturing gradient gel electrophoresis (DGGE) profiles and cluster diagrams of (A) bacterial and (B) fungal assemblages among sites on leaves from day 98 during the study. Individual bands on DGGE profiles are different operational taxonomic units. Cluster diagrams are results of unweighted pair group method with arithmetic mean (UPGMA) analysis. Codes above lanes and on cluster diagrams are site codes (see Fig. 1 for locations), and numbers in parentheses next to the site codes on the cluster diagrams are mean $\mathrm{pH}$ values during the study.

ently because most of the taxa at all of our sites were acid tolerant and present at similar abundance. The three taxa, Amphinemura, Leuctra, and Ostrocerca, that accounted for the vast majority (73-94\%) of all shredders across our sites, are considered acid tolerant (McClurg et al. 2007), and their abundance was unrelated to $\mathrm{pH}$ and $k$ in our study. There was, however, one taxon, Lepidostoma, that was fairly abundant (4$14 \%$ of all invertebrates) at some sites and its abundance explained $\sim 37 \%$ of the variation in $k$ across sites. Lepidostoma is an effective leaf shredder and its abundance has been linked to rapid leaf breakdown rates in other streams (Kobayashi and Kagaya 2005, Azevedo-Pereira et al. 2006). In our study, the abundance of Lepidostoma was positively related to $\mathrm{pH}$ and Lepidostoma has been considered acid sensitive in other streams (Raddum and Fjellheim 2003), suggesting it was a key taxon in our streams that was both sensitive to disturbance and important for leaf breakdown. Likewise, Whiles and Wallace (1995) found that recovery of Lepidostoma following insecticide and hydrologic disturbance led to restoration of relatively rapid leaf breakdown rates in other Appalachian streams. Notably, Lepidostoma were absent in acidified streams but present in both circumneutral and limed streams on the Allegheny Plateau in West Virginia (McClurg 2004, McClurg et al. 2007), and Lepidostoma returned to a Swedish river following liming (Raddum and Fjellheim 2003). It appears that reducing acidity has the potential to partially restore ecosystem function by increasing the abundance of this key shredder to some streams. Our data are consistent with other studies (e.g., 
Dangles and Guerold 2001) that have shown a few sensitive taxa can play a particularly important role in determining how acidification influences ecosystem function in streams. While restoration and monitoring commonly focus on biodiversity (i.e., species richness), and biodiversity can influence rates of leaf breakdown (e.g., Dangles and Malmqvist 2004, Dang et al. 2005), our data suggest that the loss and restoration of a few key taxa that strongly influence ecosystem function may be more important.

While differences in shredder abundance explained some of the variation in $k$ among our sites, microbial activity also was important. Both microbial community composition (Duarte et al. 2006) and activity (Webster and Benfield 1986) influence leaf breakdown, and we found clear differences in microbial-community diversity and composition and microbial function among our sites. While much attention has focused on changes in invertebrate and fish diversity resulting from acidification, much less is known about how acidification influences microbial diversity in aquatic systems. Much like shredder diversity, the diversity of bacteria and fungi differed little across the $\mathrm{pH}$ gradient of our sites. This differs from other studies that used morphological data to show reduced fungal diversity in acidified streams. For example, Chamier (1987) reported reduced fungal diversity at low $\mathrm{pH}$ across a range similar to ours ( $\mathrm{pH}$ 4.9-6.8). Likewise, Dubey et al. (1994) found fewer fungal taxa on leaves from acidic compared to reference sites in the Fernow Experimental Forest of West Virginia, where the $\mathrm{pH}$ of highly acidic streams $(\mathrm{pH}$ $3.2-4.2)$ were lower than that in any of our sites $(\mathrm{pH}>$ 4.8). Niyogi et al. (2002b) also found reduced fungal diversity in streams acidified by mine drainage, but much of the reduction occurred at $\mathrm{pH}$ levels lower $(\mathrm{pH}<4)$ than that in our sites, and the mine drainage streams also had high concentrations of metals. We know of no other studies that have used molecular approaches to examine microbial response to acidification in streams, but taxon richness $(S)$ in our individual study sites for fungi (11-18 taxa) and bacteria (19-23 taxa) was within the range reported for other, non-acidic freshwater systems for fungi ( $S=4-33$ taxa; Nikolcheva et al. 2003, Raviraja et al. 2005, Das et al. 2007) and bacteria ( $S=7-30$ taxa; Jackson et al. 2001, Lyautey et al. 2005, Das et al. 2007). We note, however, that we sampled only a single date and also that DGGE is an imperfect method in that the majority, but not all, of the populations in the microbial community are detected (Nikolcheva et al. 2003, Reche et al. 2005). As a result, there may have been changes in the presence or absence of some taxa that occurred at other times or at very low abundance in our sites, resulting in subtle changes in microbial diversity that we could not detect.

While we found no large disparity in microbial diversity, as richness or Shannon diversity, among sites, we did find substantial differences in microbial community composition. Acid-induced changes in microbial community structure have been demonstrated in soils (Pennanen et al. 1998), lakes (Methé and Zehr 1999), and stream sediments (Ben-David et al. 2004). The differences in microbial community composition, rather than diversity, may have been important in our streams. For example, Duarte et al. (2006) found that fungalspecies identity played a greater role in dictating leaf breakdown rate than did fungal species richness in streams. Community structure among our sites did not separate cleanly by $\mathrm{pH}$ across all sites, a result also found for acidified lakes (Methé and Zehr 1999), indicating that a variety of factors likely interacted to influence microbial assemblage composition. However, at the extreme ends of the $\mathrm{pH}$ gradient in our study (sites AT and BT2 in Mountain Run), the fungal and bacterial assemblages shared only $50 \%$ and $85 \%$ of their taxa, respectively. In comparison, those two sites shared $83 \%$ of their shredding-invertebrate taxa. The rates of leaf breakdown and microbial respiration were also quite different between the most acidic and circumneutral sites. Furthermore, in our respiration assays the microbial communities in AT and BT2 demonstrated adaptation to ambient $\mathrm{pH}$. It appears that acidification plays a role in shifting microbial community structure, perhaps toward taxa best adapted to acidic conditions. However, any adaptation to acidic conditions was not sufficient to produce rates of microbial respiration and leaf breakdown equivalent to those observed in the naturally buffered sites.

Had suppression of microbial activity played a major role in the pattern of reduced leaf breakdown with declining $\mathrm{pH}$, we might have seen reduced fungal biomass and microbial respiration rates that more strongly mirrored the pattern of $k$. For example, other studies have linked reduced microbial biomass (Griffith and Perry 1994, Meegan et al. 1996) and respiration (Mulholland et al. 1987, Niyogi et al. 2001) with reduced $k$ in other acidified streams. However, fungal biomass was unresponsive to $\mathrm{pH}$ in our study, a result also shown for streams in France (Dangles and Chauvet 2003). A clear pattern of reduced microbial respiration and leaf breakdown rate was apparent in Mountain Run, but this pattern held across all sites only when we excluded one site (LS2). For some reason, that site had unusually high rates of respiration on the first three dates relative to all other sties. It appears that reduced microbial activity played a role in the reduction of leaf breakdown, but there can be site to site variation in other factors that can influence this relationship. Respiration rates also may not perfectly reflect the total influence of microbial activity on leaf breakdown, such as the softening and subsequent fragmentation that results from microbial activity.

A major component of leaf processing by microbes is the secretion of extracellular enzymes that degrade leaf material to obtain organic carbon and nutrients. Different fungal taxa vary in the suite of enzymes they produce (Suberkropp et al. 1983), and like the differ- 
ences in microbial assemblage composition, we found strong differences in enzyme activity among our sites. The pattern of increasing turnover activity with increasing acidity across sites suggests a higher investment in enzyme production for decomposition by microbial films with increasing acidity. However, based on our incubation of BT2 leaves across a pH gradient, this appears to be true only for acquisition of P. For the two cellulolytic enzymes, GLUC and XYLO, the pattern of enzyme activity among sites appears to have been caused by a direct effect of $\mathrm{pH}$ on enzyme speed rather than differences in enzyme production. Indeed, there may have been reduced allocation to GLUC production in the most acidic sites (Fig. 7B). Other studies have reported higher activities of similar enzymes (e.g., Griffith et al. 1995) in more acidic streams, but they did not determine if the pattern was a result of differences in enzyme production or direct effects of $\mathrm{pH}$ on enzyme speed. Regardless of the cause, the higher activity of GLUC and XYLO did not lead to enhanced leaf breakdown in the more acidic sites. There are a suite of other enzymes involved in leaf decomposition that are sensitive to acidity (e.g., Jenkins and Suberkropp 1995), and those may or may not have behaved in a similar fashion to GLUC and XYLO.

Microbial activity on leaves can be constrained by the availability of nutrients, especially $\mathrm{N}$ and $\mathrm{P}$ (Gulis and Suberkropp 2003). The rate of leaf breakdown was unrelated to $\mathrm{NO}_{3}{ }^{-}$concentration in our sites, but we have few data for $\mathrm{N}$ concentration so we cannot preclude the possibility of variable $\mathrm{N}$ limitation across our sites that influenced leaf breakdown. However, it seems unlikely that $\mathrm{N}$ was primarily limiting, considering soluble reactive phosphorus concentration was quite low $(<1 \mu \mathrm{g} \mathrm{P} / \mathrm{L})$ in all of the streams. Further, the activity of phosphatase, an indicator of $\mathrm{P}$ limitation of microbial films (Mulholland et al. 1986), was strongly associated with variation in $k$ among sites. Phosphatase activity was also strongly related to $\mathrm{pH}$, and unlike the cellulolytic enzymes, the combined patterns of phosphatase activity across sites and for the BT2 leaves incubated at multiple $\mathrm{pH}$ values indicates an increased allocation of enzymatic effort for acquisition of $\mathrm{P}$ with increasing acidity.

Several studies have shown phosphatase activity is strongly influenced by $\mathrm{pH}$, although not always in the same manner. Like our study, some have found increased phosphatase activity in acidic streams compared to circumneutral streams (e.g., Chapelle and Goulder 1992, 1994). Our results are also similar to the pattern of phosphatase activity in an acidic lake that was limed. In that lake, phosphatase activity in the water column was high during acidic $(\mathrm{pH}=4.7)$ conditions, apparently because high aluminum concentrations blocked phosphatase substrates (Jansson 1981, Olsson 1990). Liming raised the $\mathrm{pH}$ (7.6) of the lake and phosphatase activity was lower than under acidic conditions (Olsson 1990). In contrast to our study,
Mulholland et al. (1986) found that phosphatase activity in epilithic biofilms declined with increasing acidity among streams in the Smoky Mountains, USA, along a $\mathrm{pH}$ gradient similar to ours. They implicated abiotic sequestration of $\mathrm{P}$ with aluminum hydroxides at higher $\mathrm{pH}$, and subsequently $\mathrm{P}$ limitation of microbial films as a likely cause. This phenomenon of acidification-induced mobilization of metals and $\mathrm{P}$ from soils to surface water, and subsequent abiotic binding of $\mathrm{P}$ by metal hydroxides in surface water, has been observed in acidified catchments (Kopáček et al. 2000, Norton et al. 2006). Total concentrations of aluminum in the water of all three streams used in our study declined dramatically following liming (Downey et al. 1994, Hudy et al. 2000), but we do not have enough data to disentangle the specific mechanisms that led to higher phosphatase activity in our more acidic sites. Regardless, considering the strong association between phosphatase activity and leaf breakdown rates, it appears that understanding how changing acidification status influences the bioavailability of $\mathrm{P}$ will be important for management of acidified streams. For example, other studies have suggested low nutrient levels may constrain recovery of stream invertebrates and fish when acidity is reduced by liming (McClurg et al. 2007). It may be the case that there is a delicate balance in which liming increases $\mathrm{P}$ availability by reducing soluble aluminum concentrations, but liming may also create a $\mathrm{P}$ sink through formation of metal hydroxides. How this dynamic plays out spatially and temporally in streams may be quite important in determining stream recovery.

Stream acidity in many areas will continue to change as levels of acid deposition are altered by policy decisions regarding emissions (Driscoll et al. 2001) and as restoration efforts such as liming are implemented. The sensitivity of leaf breakdown for assessing functional response to changing acidity and the potential for restoration of this ecosystem function is apparent in the continuous nature of breakdown rates relative to $\mathrm{pH}$ observed in our data. Notably, we found no clear threshold of $\mathrm{pH}$ that could be selected as a target for complete restoration of stream function. Few studies have examined the response of leaf breakdown to liming, and the results are mixed. In our study, sites below liming stations did not have leaf breakdown rates equal to those observed in the naturally buffered tributary. Care should be taken in interpreting this trend because we do not have data about leaf breakdown prior to liming, and the chemical effect of the liming was reduced in our study compared to the larger changes in $\mathrm{pH}$ observed in the first few years following the addition of limestone to each stream. Merrix et al. (2006) found that liming effectively restored leaf decomposition rates to those in nonacidified streams in Wales. McKie et al. (2006) found that while liming increased leaf breakdown by microbes, it reduced shredding by invertebrates in a Swedish stream. How well various management practices restore 
ecosystem function has yet to be determined, but leaf breakdown will be a useful tool for assessment and design of restoration strategies. The incorporation of data about both invertebrate and microbial processes occurring during leaf breakdown illuminates the mechanisms that drive functional change in response to acidification status. In particular, our results indicate that, in terms of restoring ecosystem function, future management efforts should consider targeting the restoration of key invertebrate, and possibly microbial, taxa that strongly influence ecosystem function rather than solely focusing on overall diversity (e.g., species richness). In addition, management strategies should address the geochemical mechanisms that regulate $\mathrm{P}$ availability, and how restoration actions interact with those mechanisms, to maximize the recovery of ecosystem function.

\section{ACKNOWLedgments}

We thank Beth Cheever, Tim Cooney, Josh Grainer, and Kim Witkowski for their help in the field and the laboratory. Mark Hudy and Dan Downey helped greatly with information about the liming history at the field sites. We also thank Dev Niyogi for helpful suggestions about the manuscript. This manuscript was improved by comments from two anonymous reviewers. This is publication number 3037 of the Maine Agricultural and Forest Experiment Station.

\section{Literature Cited}

APHA. 1999. Standard methods for the examination of water and wastewater. 20th edition. American Public Health Association, Washington, D.C., USA.

Azevedo-Pereira, H. V. S., M. A. S. Graca, and J. M. Gonzalez. 2006. Life history of Lepidostoma hirtum in an Iberian stream and its role in organic matter processing. Hydrobiologia 559: 183-192.

Ben-David, E. A., P. J. Holden, D. J. M. Stone, B. D. Harch, and L. J. Foster. 2004. The use of phospholipid fatty acid analysis to measure impact of acid rock drainage on microbial communities in sediments. Microbial Ecology 48: 300-315.

Chamier, A. C. 1987. Effect of $\mathrm{pH}$ on microbial degradation of leaf litter in seven streams of the English lake district. Oecologia 71:491-500.

Chappell, K. R., and R. Goulder. 1992. Epilithic extracellular enzyme activity in acid and calcareous headstreams. Archiv für Hydrobiologie 125:129-148.

Chappell, K. R., and R. Goulder. 1994. Seasonal variation of epilithic extracellular enzyme activity in three diverse headstreams. Archiv für Hydrobiologie 130:195-214.

Dang, C. K., E. Chauvet, and M. O. Gessner. 2005. Magnitude and variability of process rates in fungal diversity-litter decomposition relationships. Ecology Letters 8:1129-1137.

Dangles, O., and E. Chauvet. 2003. Effects of stream acidification on fungal biomass in decaying beech leaves and leaf palatability. Water Research 37:533-538.

Dangles, O., M. O. Gessner, F. Guerold, and E. Chauvet. 2004. Impacts of stream acidification on litter breakdown: implications for assessing ecosystem functioning. Journal of Applied Ecology 41:365-378.

Dangles, O., and F. Guerold. 1998. A comparative study of beech leaf breakdown, energetic content, and associated fauna in acidic and non-acidic streams. Archiv für Hydrobiologie 144:25-39.

Dangles, O., and F. Guerold. 2001. Influence of shredders in mediating breakdown rates of beech leaves in circumneutral and acidic forest streams. Archiv für Hydrobiologie 151:649666.

Dangles, O., and B. Malmqvist. 2004. Species richnessdecomposition relationships depend on species dominance. Ecology Letters 7:395-402.

Das, M., T. V. Royer, and L. G. Leff. 2007. Diversity of fungi, bacteria, and actinomycetes on leaves decomposing in a stream. Applied and Environmental Microbiology 73:756767.

Downey, D. M., C. F. French, and M. Odom. 1994. Low cost limestone treatment of acid sensitive trout streams in the Appalachian mountains of Virginia. Water, Air and Soil Pollution 77:49-77.

Driscoll, C. T., G. B. Lawrence, A. J. Bulger, T. J. Butler, C. S. Cronan, C. Eagar, K. F. Lambert, G. E. Likens, J. L. Stoddard, and K. C. Weathers. 2001. Acidic deposition in the northeastern United States: sources and inputs, ecosystem effects, and management strategies. BioScience 51:180-198.

Duarte, S., C. Pascoal, F. Cássio, and F. Bärlocher. 2006. Aquatic hyphomycete diversity and identity affect leaf litter decomposition in microcosms. Oecologia 147:658-666.

Dubey, T., S. L. Stephenson, and P. J. Edwards. 1994. Effect of $\mathrm{pH}$ on the distribution and occurrence of aquatic fungi in six West Virginia mountain streams. Journal of Environmental Quality 23:1271-1279.

Eggleton, M. A., E. L. Morgan, and W. L. Pennington. 1996. Effects of liming on an acid-sensitive southern Appalachian stream. Restoration Ecology 4:247-263.

Gessner, M. O., and E. Chauvet. 2002. A case for using litter breakdown to assess functional stream integrity. Ecological Applications 12:498-510.

Griffith, M. B., and S. A. Perry. 1994. Fungal biomass and leaflitter processing in streams of different water chemistry. Hydrobiologia 294:51-61.

Griffith, M. B., S. A. Perry, and W. B. Perry. 1995. Leaf litter processing and exoenzyme production on leaves in streams of different $\mathrm{pH}$. Oecologia 102:460-466.

Gulis, V., and K. Suberkropp. 2003. Leaf litter decomposition and microbial activity in nutrient-enriched and unaltered reaches of a headwater stream. Freshwater Biology 48:123134.

Herlihy, A. T., P. R. Kaufmann, M. R. Church, P. J. Wigington, J. R. Webb, and M. J. Sale. 1993. The effects of acidic deposition on streams in the Appalachian mountain and piedmont region of the Mid-Atlantic United States. Water Resources Research 29:2687-2703.

Hildrew, A. G., C. R. Townsend, J. Francis, and K. Finch. 1984. Cellulytic decomposition in streams of contrasting $\mathrm{pH}$ and its relationship with invertebrate community structure. Freshwater Biology 14:323-328.

Hudy, M., D. M. Downey, and D. W. Bowman. 2000. Successful restoration of an acidified native brook trout stream through mitigation with limestone sand. North American Journal of Fisheries Management 20:453-466.

Jackson, C. R., P. F. Churchill, and E. E. Roden. 2001. Successional changes in bacterial assemblage structure during epilithic biofilm development. Ecology 82:555-566.

Jansson, M. 1981. Induction of high phosphatase activity by aluminum in acid lakes. Archiv für Hydrobiologie 93:32-44.

Jenkins, C. C., and K. Suberkropp. 1995. The influence of water chemistry on the enzymatic degradation of leaves in streams. Freshwater Biology 33:245-253.

Kleinbaum, D. G., L. L. Kupper, and K. E. Muller. 1988. Applied regression analyses and other multivariate methods. Kent Publishing Company, Boston, Massachusetts, USA.

Kobayashi, S., and T. Kagaya. 2005. Hot spots of leaf breakdown within a headwater stream reach: comparing breakdown rates among litter patch types with different macroinvertebrate assemblages. Freshwater Biology 50:921929. 
Kopáček, J., J. Hejzlar, J. Borovec, P. Porcal, and I. Kotorova 2000 Phosphorus inactivation by aluminum in the water column and sediments: lowering of in-lake phosphorus availability in an acidified watershed-lake ecosystem. Limnology and Oceanography 45:212-225.

Lyautey, E., C. R. Jackson, J. Cayrou, J.-L. Rols, and F. Garabétian. 2005. Bacterial community succession in natural river biofilm assemblages. Microbial Ecology 50:589-601.

McClurg, S. E. 2004. Stream ecosystem response to mitigative limestone treatment in acid impaired, Central Appalachian streams. Thesis. West Virginia University, Morgantown, West Virgina, USA.

McClurg, S. E., J. T. Petty, P. M. Mazik, and J. L. Clayton. 2007. Stream ecosystem response to limestone treatment in acid-impacted watersheds of the Allegheny plateau. Ecological Applications 17:1087-1104.

McKie, B. G., Z. Petrin, and B. Malmqvist. 2006. Mitigation or disturbance? Effects of liming on macroinvertebrate assemblage structure and leaf-litter decomposition in the humic stream of northern Sweden. Journal of Applied Ecology 43: 780-791.

Meegan, S. K., S. A. Perry, and W. B. Perry. 1996. Detrital processing in streams exposed to acidic precipitation in the Central Appalachian mountains. Hydrobiologia 339:101110.

Merritt, R. W., and K. W. Cummins. 1996. An introduction to the aquatic insects of North America. Third edition. Kendall/Hunt Publishing, Dubuque, Iowa, USA.

Merrix, F. L., B. R. Lewis, and S. J. Ormerod. 2006. The effects of low $\mathrm{pH}$ and palliative liming on beech litter decomposition in acid-sensitive streams. Hydrobiologia 571:373-381.

Methé, B. A., and J. P. Zehr. 1999. Diversity of bacterial communities in Adirondack lakes: do species assemblages reflect lake water chemistry? Hydrobiologia 401:77-96.

Mulholland, P. J., C. T. Driscoll, J. W. Elwood, M. P. Osgood, A. V. Palumbo, A. D. Rosemond, M. E. Smith, and C. Schofield. 1992. Relationships between stream acidity and bacteria, macroinvertebrates, and fish: a comparison of north temperate and south temperate mountain streams, USA. Hydrobiologia 239:7-24.

Mulholland, P. J., J. W. Elwood, A. V. Palumbo, and R. J. Stevenson. 1986. Effect of stream acidification on periphyton composition, chlorophyll and productivity. Canadian Journal of Fisheries and Aquatic Sciences 43:1846-1858.

Mulholland, P. J., A. V. Palumbo, J. W. Elwood, and A. Rosemond. 1987. Effects of acidification on leaf decomposition in streams. Journal of the North American Benthological Society 6:147-158.

Muyzer, G., and K. Smalla. 1998. Application of denaturing gradient gel electrophoresis (DGGE) and temperature gradient gel electrophoresis (TGGE) in microbial ecology. Antoine Van Leeuwenhoek International Journal of General and Molecular Microbiology 73:127-141.

Newell, S. Y., T. L. Arsuffi, and R. D. Fallon. 1988. Fundamental procedures for determining ergosterol content of decaying plant material by liquid chromatography. Applied and Environmental Microbiology 54:1876-1879.

Nikolcheva, L. G., T. Bourque, and F. Bärlocher. 2005. Fungal diversity during initial stages of leaf decomposition in a stream. Mycological Research 109:246-253.

Nikolcheva, L. G., A. M. Cockshutt, and F. Bärlocher. 2003. Determining diversity of freshwater fungi on decaying leaves: comparison of traditional and molecular approaches. Applied and Environmental Microbiology 69:2548-2554.

Niyogi, D. K., W. M. Lewis, Jr., and D. K. McKnight. 2001. Litter breakdown in mountain streams affected by mine drainage: biotic mediation of abiotic controls. Ecological Applications 11:506-516

Niyogi, D. K., W. M. Lewis, Jr., and D. K. McKnight. $2002 a$. Effects of stress from mine drainage on diversity, biomass, and function of primary producers in mountain streams. Ecosystems 5:554-567.

Niyogi, D. K., W. M. Lewis, Jr., and D. K. McKnight. $2002 b$. Fungal communities and biomass in mountain streams affected by mine drainage. Archiv für Hydrobiologie 155: 255-271.

Niyogi, D. K., W. M. Lewis, and D. K. McKnight. 2003 a. Direct and indirect effects of mine drainage on bacterial processes in mountain streams. Journal of the North American Benthological Society 22:276-291.

Niyogi, D. K., K. S. Simon, and C. R. Townsend. 2003 b. Breakdown of tussock grass in streams along a gradient of agricultural development in New Zealand. Freshwater Biology 48:1698-1708.

Norton, S., I. Fernandez, A. Amirbahman, K. Coolidge, and T. Navratil. 2006. Aluminum, phosphorus, and oligotrophyassembling the pieces of the puzzle. Verhandlungen Internationale Vereinigung für Theoretische und Angewandte Limnologie 29:1877-1886.

Olsson, H. 1990. Phosphatase activity in relation to phytoplankton composition and $\mathrm{pH}$ in Swedish lakes. Freshwater Biology 23:353-362.

Pennanen, T., H. Fritze, P. Vanhala, O. Kiikkilä, S. Neuvonen, and E. Bååth. 1998. Structure of a microbial community in soil after prolonged addition of low levels of simulated acid rain. Applied and Environmental Microbiology 64:21732180.

Raddum, G. G., and A. Fjellheim. 2003. Liming of River Audna, Southern Norway: a large-scale experiment of benthic invertebrate recovery. Ambio 32:230-234.

Raviraja, N. S., L. G. Nikolcheva, and F. Bärlocher. 2005. Diversity of conidia of aquatic hyphomycetes assessed by microscopy and DGGE. Microbial Ecology 49:301-307.

Reche, I., E. Pulido-Villena, R. Morales-Baquero, and E. O. Casamayor. 2005. Does ecosystem size determine aquatic bacterial richness? Ecology 86:1715-1722.

Schindler, D. W. 1988. Effects of acid rain on freshwater ecosystems. Science 239:149-157.

Sinsabaugh, R. L., M. M. Carriero, and S. Alvarez. 1991. Enzymes and microbial dynamics of litter decomposition. Pages 1147-1160 in R. J. Chrost, editor. Microbial enzymes in aquatic environments. Springer-Verlag, New York, New York, USA.

Sinsabaugh, R. L., M. M. Carreiro, and D. A. Repert. 2002. Allocation of extracellular enzymatic activity in relation to litter composition, $\mathrm{N}$ deposition, and mass loss. Biogeochemistry 60:1-24.

Suberkropp, K., T. L. Arsuffi, and J. P. Anderson. 1983. Comparison of degradative ability, enzymatic activity, and palatability of aquatic hyphomycetes grown on leaf litter. Applied and Environmental Microbiology 46:237-244.

Townsend, C. R., A. G. Hildrew, and J. Francis. 1983. Community structure in some southern English streams: the influence of physicochemical factors. Freshwater Biology 13:521-544.

Wallace, J. B., S. L. Eggert, J. L. Meyer, and J. R. Webster. 1997. Multiple trophic levels of a forest stream linked to terrestrial litter inputs. Science 277:102-104.

Weatherley, N. S. 1988. Liming to mitigate acidification in freshwater ecosystems: a review of the biological consequences. Water, Air and Soil Pollution 39:421-438.

Webster, J. R., and E. F. Benfield. 1986. Vascular plant breakdown in freshwater ecosystems. Annual Review of Ecology and Systematics 17:567-594.

Whiles, M. R., and J. B. Wallace. 1995. Macroinvertebrate production in a headwater stream during recovery from anthropogenic disturbance and hydrologic extremes. Canadian Journal of Fisheries and Aquatic Sciences 52:2402-2422. 